\title{
YOUTH AND POLITICS IN BOTSWANA
}

\section{Tidimane Ntsabane and Chris Ntau}

Tidimane Ntsabane is a senior lecturer in the Sociology Department of the University of Botswana Phone: + 267355 2737; Fax: +267 3554196

e-mail: NTSABANE@mopipi.ub.bw.

Dr Chris Ntau is a lecturer in the Sociology Department of the University of Botswana P / Bag UB 00705, Gaborone, Botswana Phone: +267 355 2675; Fax: +267 3554196 e-mail: NTAUCH@mopipi.ub.bw

\begin{abstract}
This paper examines the extent and nature of electoral participation in general and that of youth in particular and attempts an explanation. It draws on reports from the Independent Electoral Commission (IEC) and its predecessor, the Elections Office, and on opinion surveys carried out by the Democracy Research Project of the University of Botswana (DRP). It argues that the poor participation of youth in politics in Botswana in general and in elections in particular is rooted in traditional Tswana culture which limits the participation of youth in public affairs. This culture is reproduced by the main socialising agents in society such as the family, the school system, political parties, and the media.
\end{abstract}

\section{INTRODUCTION}

The last century witnessed three major democratic processes. First, there were the decolonisation winds that blew across the globe and brought independence and nationhood to much of the world. Second, there was the democratisation process whereby 140 of the world's 189 countries had multiparty electoral systems and two-thirds of humanity lived under such systems. Third, there was the disengagement/disillusionment with the political processes, with falling rates of participation, especially among the young. Africa has been no exception to these trends. 
Botswana gained its independence and nationhood in 1966. Independence was marked by the advent of a new Constitution enshrining a competitive, multiparty electoral system guaranteeing open, free and fair elections. During four decades of uninterrupted electoral democracy the country has held nine elections, with no fewer than four political parties participating in each. Although competitive elections, though an important indicator of the relative openness of the political system, are, on their own, not a sufficient condition for the development of a democratic culture they do provide an important opportunity for the people to express their views on the policies and programmes of both the government of the day and of the other contenders for political office.

As we have just passed the half-century of Botswana's democracy it is appropriate to assess the extent and nature of youth participation in politics in general and elections in particular - the youth, after all, are not only the present but are also the future. They are potential voters and participants in the electoral process in the present and will be so in the future. They will also become the parents who provide political socialisation to a future generation of political participants.

The youth currently represent a significant part of the population of Botswana and will do so in the foreseeable future. This paper focuses on the changing trends and patterns in their participation in politics in general and the electoral process in particular and examines the nature of their involvement.

\section{THE SIGNIFICANCE OF THE YOUTH}

Young people currently represent a significant part of the world's population. At the time of the 1995 International Conference on Population and Development about 20 per cent of the entire population of the world was in the age group 15 to 24 years. Demographic trends in Africa show that about 50 per cent of the continent's population is below the age of 18 and an extraordinarily high percentage is between the ages of 15 and 25. Although globally there has been a decline in fertility and consequently in population growth rates Africa will continue to experience population growth driven by both natural increase and the 'momentum effect' (Nair 2006). Momentum brings larger and larger cohorts into parental age groups, so that even as fertility declines considerably, the number of births is still high.

There is concern in many Third World countries, especially in Africa, about the growing youth bulge in the population, or what population economists have referred to as the demographic bonus (Nair 2006). The United Nations estimates that in 2000 some 40 per cent of the adult population in more than 100 countries was in the age group 15 to 29 years and many of these countries are in Africa. 
This bulge is a consequence of previous decades of high fertility rates and falling infant and child mortality rates.

Botswana has been no exception to these demographic trends; it has one of the fastest-growing populations. As population statistics from the three postindependence censuses show the de facto population in 1971 was 596944 , increasing to 941027 in 1981, 1326796 in 1991, and 1678891 in 2001. These figures show a natural rate of increase (percentage per annum) of 3,1 per cent between 1971 and 1981, 3,4 per cent between 1981 and 1991, and 1,7 per cent between 1991 and 2001.

The proportion of the population aged under 15 has consistently remained high: 44 per cent in 1971, 48,8 per cent in 1981, 42 per cent in 1991 and 36,6 per cent in 2001.The 1991 census further shows that 60 per cent of the population is under 30. Botswana's population is thus a youthful one, with implications for demands on education, training, health, housing and jobs. As a result of these demographic characteristics there has been a renewed interest in and focus on the youth.

Different societies have different definitions of youth, with age the most common and primary criterion. In Botswana, as is true of much of Southern Africa, it is the 12 to 29 cohort. The literature, however, recognises other common markers such as a period of physical development or a socio-cultural phenomenon (Rogers 1985). This paper adopts the age group 12 to 29 as the marker. Traditional Tswana society, however, did not use age but an elaborate series of rites known as bogwera (for men) and bojale (for women). A person who had not passed through one of these rites was always regarded as a boy or girl, no matter how old he or she might actually be. He or she could not take part in tribal discussions or marry.

\section{YOUTH AND POLITICS}

The period between the 1960s and the 1990s witnessed colonial struggles, democratisation and, latterly, periods of disengagement from and disillusionment with democratic processes. Southern Africa was, in much of its colonial past, dominated by apartheid and inherently undemocratic colonial rule. These were followed by protracted struggles by African nationalist movements for political independence; struggles that were to culminate in the indigenisation of political control and multi-party electoral systems. Some would later become one-party states and, still later, multiparty democracies again (Legum 1999).

Young people have been at the centre of these trends. Organs of civil society such as student organisations, trades unions, churches and women's organisations have played leading roles in the various waves of the struggle for decolonisation and democracy. With the success of the democratisation process these bodies are 
now faced with the challenges of participation in the new political dispensation. The strength, depth and sustainability of the democratisation gains are dependent on the extent of citizen participation, especially among the youth. Botswana's youth have not been as involved as their counterparts in other parts of the region, such as South Africa or Zimbabwe. They do, to a limited extent, involve themselves in house-to-house campaigns on behalf of political parties, hold fund-raising events for their parties, and organise political rallies (meetings), and their youth wings have been vocal on some issues of regional, national and party interest.

The ultimate contribution, however, is the extent to which they are able to influence who is elected since elections provide an important opportunity for the electorate to express its preferences on the policies and programmes of both the government of the day and those of the other contenders for political office. What the youth think about elections and the electoral system is important to the way they view their leaders and their motivation to go to the polls when so required. There have been limitations on the extent and nature of this participation.

The most vocal segment of the youth movement has been students at the University of Botswana. In the 1980s and 1990s they made their voices heard on many international issues such as state relations, disarmament, and the aggressive behaviour of rogue states such as the racist regime of South Africa. At the local level they staged demonstrations and marches against the government in response to the corruption scandals that rocked the country in the 1990s and also to the disappearance of school children and ritual murders. However, in recent years they have been more vocal about a narrow set of localised welfarist issues such as food, living allowances, and sponsorships.

The youth wings of the major political parties such as the Botswana Democratic Party (BDP) and the Botswana National Front (BNF) have operated with little influence and do not have agendas that set them apart from the main party. They have thus emerged more as mirrors of the larger party. Anecdotal evidence even suggests that the parties' youth wings, as well as their women's wings, are weak and dysfunctional (Modise 2005).

This relatively conservative tradition is rooted in a traditional Tswana political culture that does not consider public affairs a domain for youth. Traditionally, political power is based on age and centres on a person's social standing. Groups such as minorities, women, and young people were not expected to be leaders or to contest for leadership positions. The youth, as Somolekae (1989) notes, are traditionally believed not to be mature enough and were, and still are, excluded from the political process, a culture that is still strong and influences who is elected to political and civic office. This lack of a democratic ethic tends to permeate all major social institutions of society and is a survivor from pre-colonial through colonial into post-colonial society. Youth, like women, are considered 
minors, whether in the family, the polity, the economy, religion, or education. Whenever the youth attempt to make an impact on policy-making there is mistrust, due primarily to differences in political values and behaviour.

\section{YOUTH AND ELECTIONS}

Elections have, for a long time, been a feature of many African political systems. They have varied in form and meaning but all tended to represent institutionalised procedures for the choosing of officeholders. Much of pre-colonial Africa, Botswana being no exception, was characterised by the predominance of chiefdom politics. The most significant political office was that of chief and chiefdoms had elaborate traditional procedures for filling the office. This system may not have been open enough, as the final decision was often taken by a small council of elders, but it did allow for lively interest and strong opinions. Political institutions allowed very limited access to traditionally excluded groups such as women, minorities and children or youth, which were marginalised, with only the elders, males, and dominant tribal groups involved.

The advent of colonialism brought with it a new system of rule. In some parts of the continent, however, it left chiefly rule to a large extent untouched for as long as it was applied to the African population and not the European, calling it 'indirect rule'. Botswana was one of the countries in which this was the case.

Legislatively the European Advisory Council (EAC) and the Native Advisory Council (NAC) were advisory bodies to the colonial administration. The NAC was made up of chiefs and 'councillors' chosen in a kgotla. As Mgadla \& Campbell (1989) note, there was, in practice, no effective participation as chiefs nominated these councillors without adequate popular participation in the kgotla. The council reflected some element of continuity with the pre-colonial order in two ways. Firstly, it brought chiefs into a new system of rule. Secondly, it continued the exclusion and political marginalisation of youth, women, and tribal minorities.

Independence was marked by the advent of a new Constitution which ushered in a competitive, multiparty electoral system that guarantees open, free and fair elections every five years for citizens meeting the minimum voting age. What, then, is the extent of youth electoral participation, and what is the meaning of this participation, or the lack of it?

\section{ELECTORAL PARTICIPATION IN THE PAST THREE DECADES}

Botswana has, in general, recorded fairly high levels of electoral participation (See Mfundisi in this issue, p 84 Table 1. The country, however, does not fare very well when compared to other democracies which hold elections. A survey by the 
International Institute for Democracy and Electoral Assistance (International IDEA 1997) of electoral participation in 177 countries across the world shows increasing overall participation between 1945 and 1990. Some 140 countries out of 189 hold multiparty elections and two-thirds of the world's population lives in these countries.

Botswana's turnout was lower than those of 14 other African countries featured in the IDEA survey which have held two or more elections between 1945 and 1997. The countries were Mauritius (six elections - 82,5\%), Namibia (two $-80,4 \%$ ), Comoros (two - 75,7\%), Cape Verde (two - 75,6\%), Madagascar (four $-72,5 \%$ ), Togo (four $-69,3 \%$ ), Lesotho (three $-65,2 \%$ ), Benin (two $-60,1 \%$ ), Zimbabwe (five - 58,8\%), Cameroon (three - 56,3\%), The Gambia (six - 55,6\%), Uganda (three - 50,6\%), Nigeria (three $-47,6 \%$ ), and Sierra Leone (three-46,8\%). Clearly Botswana might be said to suffer from having held more elections than these countries but even if one takes into consideration only elections conducted after 1990, the 44,5 per cent voter turnout still falls below that of 15 others.

While the overall voter turnout in most of Botswana's recent elections shows participation rates above 65 per cent, recent DRP surveys show lower levels of participation among the youth (see Tables 3 and 4). This trend is also true among men, compared to women. The low rate of participation is especially astonishing as the youth are a relatively better educated generation of voters; have lived all their lives under the present multiparty system and are thus free of the excesses of the past; and seem to prefer the current electoral system over chieftaincy (see Table 1).

Many adult voters are said to be reluctant to vote in every election because, in their opinion, they determined at the very first election in 1965 who should lead them. In their view, the tradition is that you elect or select the leader once and he or she remains leader until he or she dies. This tradition of selecting the chief is said to be an important factor limiting political participation in Botswana. As Table 1 illustrates, this explanation cannot hold true for the youth.

In the 1999 DRP opinion poll participants were asked whether they had registered to vote in the October 1999 election. A significant majority $(74,1 \%)$ of those aged 18 to 20 indicated that they had not registered (see Table 2). The percentage of those who registered increased with an increase in age. For example, almost 47 per cent of the sampled population aged 21 to 30 indicated that they had done so. A higher percentage (71\%) of those older than 31 reported that they had registered.

The March 1999 opinion poll conducted by the DRP also sounded out participants on whether they would vote in the 1999 elections. Only 42 per cent of people in the age group 18 to 20 said they would, compared to 80 per cent of respondents aged 31 and older (see Table 3). Generally, the youth were not 
enthusiastic about going to the polls in October 1999 to cast their vote. Even in the latest general election (2004) their participation was not satisfactory. Thus, voter apathy among the young requires thorough investigation.

Low participation by the youth has, for some time, been recognised as a problem area for the country's political system by, among others, the Independent Electoral Commission (IEC), political parties, the Botswana National Youth Council, the media, and various political commentators. It is also not unique to Botswana or Southern Africa. Japan, the United States of America, and other mature democracies are faced with the same problem. One magazine survey in the US reports that 69 per cent of young Americans see government as irrelevant

Table 1

Age and Preferred Form of Government

\begin{tabular}{|l|c|c|}
\hline Age & Electoral System & Chieftaincy \\
\hline $21-29$ & 83,2 & 16,9 \\
\hline $30-39$ & 74,0 & 26,0 \\
\hline $40-52$ & 70,1 & 29,0 \\
\hline $53-64$ & 60,9 & 39,1 \\
\hline $65+$ & 46,4 & 53,6 \\
\hline
\end{tabular}

Source: DRP 1989

Table 2

Registration by Age Group

1999 Poll

\begin{tabular}{|l|rr|rr|r|}
\hline Age & \multicolumn{2}{|c|}{ Registered } & \multicolumn{3}{|c|}{} \\
\hline & \multicolumn{2}{|c|}{ Yes-number (\%) } & \multicolumn{2}{|c|}{ No-number (\%) } & Total \\
\hline $18-20$ & 146 & $(25,9)$ & 417 & $(74,1)$ & 563 \\
\hline $21-30$ & 685 & $(46,7)$ & 783 & $(53,3)$ & 1468 \\
\hline $31-99$ & 1614 & $(70,6)$ & 671 & $(29,4)$ & 2285 \\
\hline Total & 2445 & $(56,6)$ & 1871 & $(43,4)$ & 4316 \\
\hline
\end{tabular}

Source: DRP 1999 
to their lives. Massey (1967) raises the same problems in relation to Japanese youth. These trends are not surprising since whatever the minimum legal age for holding office government is always in the hands of middle-aged and older people. The youth are a category normally not associated with political decision-making, this being so because most cultures view youth as belonging to 'the future'. The assumption is that as today's rulers retire young politicians will become rising stars and spokespersons for a new generation.

Table 3

Intention to Vote, by Age Group

\begin{tabular}{|l|cc|cc|c|}
\hline Age & \multicolumn{5}{|c|}{ Intending to vote } \\
\hline & Yes - number & $(\%)$ & No- number & $(\%)$ & Total \\
\hline $18-20$ & 239 & $(42,4)$ & 252 & $(44,7)$ & 564 \\
\hline $21-30$ & 913 & $(62,1)$ & 402 & $(27,3)$ & 1470 \\
\hline $31-99$ & 1836 & $(80,4)$ & 274 & $(12,0)$ & 2284 \\
\hline Total & $\mathbf{2 9 8 8}$ & $\mathbf{( 6 9 , 2 )}$ & $\mathbf{9 2 8}$ & $\mathbf{( 2 1 , 5 )}$ & 4318 \\
\hline
\end{tabular}

Source: DRP 1989

\section{PARTY SUPPORT AMONG THE YOUTH}

In terms of party support among the youth (12-30 age group), the DRP 1989 opinion poll showed the BNF commanding some 36 per cent of the support compared to the BDP $(23 \%)$. The BPP trailed with 19 per cent (see Table 4$)$. This positive showing by the opposition was not sustained a decade later when, according to the $1999 \mathrm{DRP}$ poll results, the BNF's popularity amongst the youth appeared to have declined.

Table 5 shows party support based on the 1999 DRP opinion poll results. The popularity of the BNF seems to have diminished, with young people aged between 21 and 30 showing their preference for the BDP. The BDP led other parties by 40,4 per cent with the BNF, which fared better among the youth in the 1989 polls, lagging behind it with 21,5 per cent. The Botswana Congress Party (BCP) and Botswana People's Party obtained 7,2 per cent and 1,2 per cent respectively. A similar pattern is repeated for 18 to 20 year olds. Prior to the 1999 general election the Botswana government acceded to opposition party demands for, among other things, lowering the voting age from 21 to 18, establishing the IEC, and extending the franchise to Batswana abroad. These reforms would, it was 


\section{Table 4}

Party Support, by Age Group

1989

\begin{tabular}{|l|rc|cc|cc|cc|}
\hline Age & \multicolumn{2}{|c|}{ None } & \multicolumn{2}{c|}{ BDP } & \multicolumn{2}{|c|}{ BNF } & \multicolumn{3}{|c|}{ BPP } \\
\hline & number & $(\%)$ & \multicolumn{2}{|c|}{ number } & $(\%)$ & number & $(\%)$ & \multicolumn{2}{|c|}{ number } & $(\%)$ \\
\hline $21-30$ & 51 & $(37,2)$ & 334 & $(22,9)$ & 270 & $(36,8$ & 39 & $(19,0)$ \\
\hline $31-40$ & 36 & $(26,3$ & 399 & $(27,4)$ & 214 & $(29,2)$ & 47 & $(22,9)$ \\
\hline $41-50$ & 23 & $(16,8$ & 354 & $(24,3)$ & 12 & $(17,3)$ & 51 & $(24,9)$ \\
\hline $51-60$ & 11 & $(8,0)$ & 160 & $(11,0)$ & 54 & $(7,4)$ & 32 & $(15,6)$ \\
\hline $61-70$ & 5 & $(3,6)$ & 109 & $(7,5)$ & 32 & $(4,4)$ & 21 & $(10,2)$ \\
\hline $71+$ & 4 & $(2,9)$ & 65 & $(4,5)$ & 20 & $(2,7)$ & 10 & $(4,9)$ \\
\hline Total & 130 & $(94,8)$ & 421 & $(97,6)$ & 717 & $(97,8)$ & 200 & $(97,5)$ \\
\hline
\end{tabular}

Source: DRP 1989

believed, benefit the opposition parties. The lowering of the voting age, however, seems not to have benefited the BNF, which, over the years, had been attracting young people to its rallies.

Despite these shifts in party support among the youth most political parties have ignored them and youth issues in their manifestos (Raditlhokwa 1999). The BDP and BNF, for instance, mentioned the plight of women, children and other vulnerable groups, but made no direct reference to the youth. The BNF went further, pledging to reserve 30 per cent of all eligible positions for women, but said nothing about the youth.

In the 1999 and 2004 general election, however, the BDP did attempt to appeal to the youth vote through some innovative youth-targeted advertising. Other campaign strategies (largely entertainment focused) that were in tune with the youth included the use of music groups (especially groups that play music loved by most youth, such as kwaito) at their political rallies. The organisation of music competitions by BDP youth choirs at both regional and national levels has also been used to attract young people, who have few places of entertainment to go to. Another strategy has been the holding of regional beauty pageants, choosing a 'Miss BDP Youth' and, in the process, raising money for the party as well attracting young people. Arguably, the popularity of the BDP among the youth in recent years, as reflected in the DRP 1999 opinion poll and the IEC Voter Apathy Study (IEC 2002), owes much to these innovative skills and strategies. 


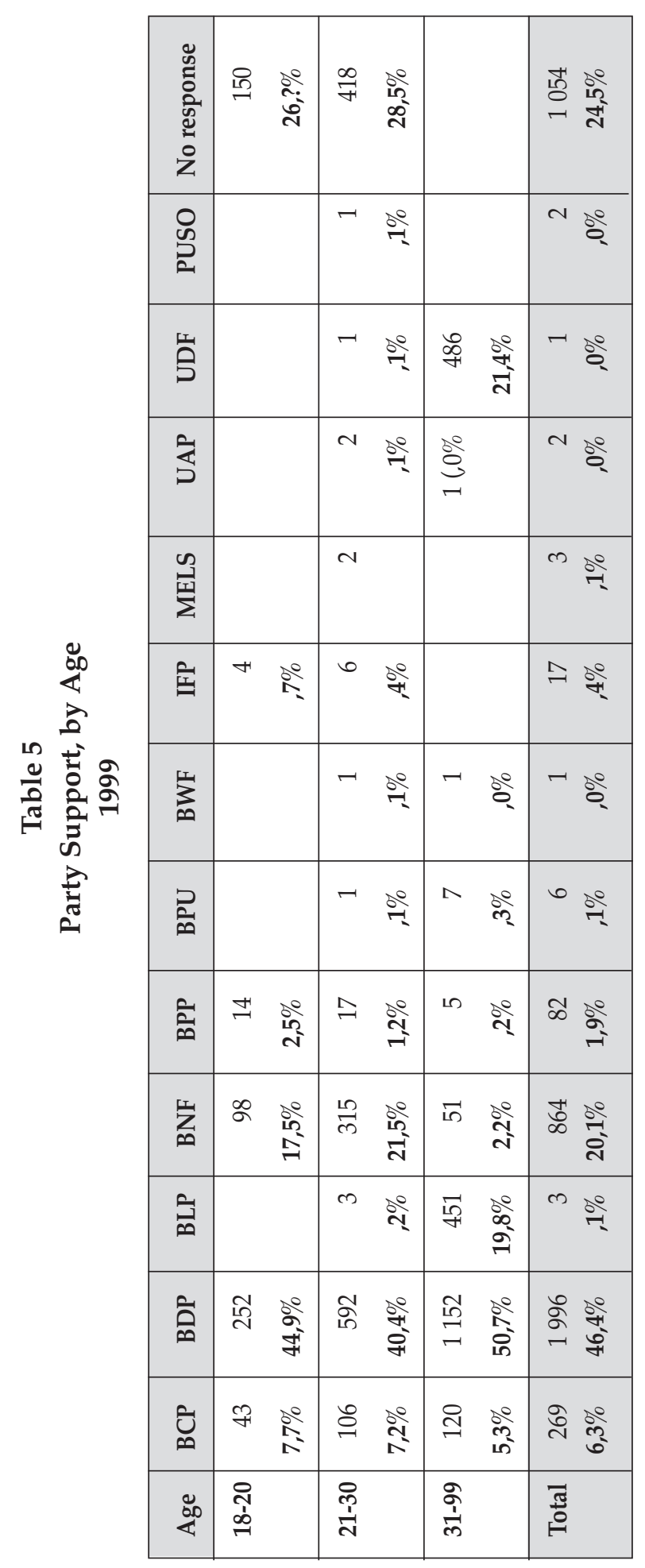

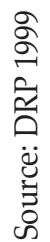




\section{CONCLUSION}

The reason for voter apathy and limited political involvement among young people may be a traditional political culture in Africa that limits political involvement to elderly males, to the exclusion of women and young people. The pre- and post-independence periods of transition did not provide sufficient socialisation to break this lack of a democratic ethic amongst these marginalised groups. A political culture in general, and a democratic culture in particular is the product of a complex process of socialisation. The human infant is born a political tabula rasa and acquires the necessary political values, beliefs and attitudes through socialisation. Somewhere between the years of early childhood and late adolescence the youth are expected to learn the skills and values which prepare them for adulthood. Key to this process are social institutions such as the family, school system, media and political parties.

The family, in its varied forms across and within cultures, is widely regarded as the most fundamental of all the agencies of socialisation and is often referred to as the 'nursery of our humanness'. If we owe so much of our humanness to the family surely it must play an important role in the process of political socialisation? Does it preach and practise democracy and electoral politics that might broadly be referred to as a democratic ethic? Does it provide opportunities for learning and living values and attitudes that are democratic?

In traditional Tswana society the family is not a democratic institution. As in other institutions, youth and women are regarded as incapable of making major decisions and thus never learn to live democratically or to develop values and attitudes that can be referred to as a democratic ethic. This marginalisation seems to have been carried on into the new post-independence political culture.

The modern Tswana family is also hampered in two other ways from breaking with this past. Firstly, it competes with other agencies of socialisation such as the school, which, as Prewitt (1971, p 14) notes, 'monopolises the time and instruction of youth during the impressionable years of late childhood and early adolescence'. Because young people spend most of their early years in formal institutions such as schools, they have increasingly become products of such agencies rather than of the family. Secondly, parents, key agents of socialisation, are also new to the post-colonial political culture - they have been educated in the past but have to teach the youth in the present. Also, within families issues relating to politics are never discussed (IEC 2002).

The education system is another important agency of political socialisation - schools are places where the young could learn and live democratically. In practice, however, students are commonly regarded as too young and immature and therefore incapable of exercising their discretion properly. They are supposed 
to learn about democratic institutions and how they work on the one hand and gain a knowledge and understanding of Setswana culture and traditions on the other. These may contradict one another. The predominant view; one that seems to be in line with Tswana culture and tradition, is summed up by Ramatsui (1989, p 90), when he observes that 'Pupils because of their relative immaturity can be given only a limited voice in any important decisions affecting the school community.'

Phorano (1989), among others, decries the present education system in Botswana, seeing it as authoritarian and incapable of developing a democratic culture. This authoritarianism is enforced through a rigid command system that puts the headmaster and teacher at the top of the hierarchy which enforces discipline, and puts the student at the receiving end of the system. This is not only limited to governance. The classroom culture is also one of teacher dominance, with the teacher seen as custodian of the truth and the fount of unquestionable knowledge. Critical thinking is discouraged and seen as disrespectful; an attitude that pervades all levels of the educational system. It is only at the level of tertiary education that there is an element of representative governance in student affairs, though the head of the institution still reigns supreme on all matters pertaining to it. Students in these tertiary institutions are still viewed by authorities with suspicion and mistrust when they challenge decisions.

Political parties are another important agency of socialisation. As the central institutions of electoral politics they are expected to register voters as party members and encourage them to participate in political events, including elections. In practice, though, they tend to attract very few registered members, especially among the youth. The main strategies for attracting supporters have been through 'Freedom Square', study groups, leaflets, and house-to-house campaigns. There are obvious limitations to each of these strategies. Freedom Square political rallies - open-air meetings addressed by political parties - have proved to be of limited appeal to the youth. The timing of meetings and frequent use of insulting language may have had the effect of discouraging young voters, appealing more to those already affiliated. Study groups as a mobilisation strategy are also of very limited appeal as they are used sparingly and are often targeted at party membership.

House-to-house campaigns are a recent phenomenon, their use limited to periods immediately before general elections. While it may be too early to judge their effectiveness, it is evident that they are not appealing to young voters as authority patterns in the home centre on parents or the oldest person at home. The use of youth-friendly campaign strategies, as the BDP has shown, could bear some fruit. Campaign strategies with an element of entertainment blended 
with a political message may prove acceptable to entertainment-starved young people.

The media are another important institution in political socialisation and potentially very influential in spreading values and beliefs. The youth are relatively more educated than their parents and better placed materially to access newspapers, radio, television and magazines. The critical question is how much political content should be included, and with what audience in mind.

Although the youth are relatively better educated than their parents they lack a democratic culture. This is a very worrying trend, especially in a society where some 60 per cent of the population is under the age of 30 and the future agents of socialisation. One important way to ensure the survival of any electoral system is not only to apply the law to the letter but also to develop a democratic culture. What the average citizen, and the youth in particular, thinks about politics, political processes and elections, and the electoral system is of importance to how they view their leaders and what may motivate them to go to the polls when so required. Should a significant part of the population lose confidence in the electoral system the rulers lose their legitimacy. It is a crisis of confidence that does not happen overnight. The family, the school system, the media, and political parties play an important role in the existence or absence of certain attitudes to the system. They are important agents of political socialisation and voter educators must take them into account.

\section{- REFERENCES}

Botswana Democratic Party. 1994. Election Manifesto. Gaborone: Printing and Publishing Company.

Botswana National Front. 1994. Manifesto for General Elections. Gaborone.

Democracy Research Project, Opinion Poll Reports 1989 and 1999.

Hayward, F. 1987. Elections in Independent Africa. London: Westview.

Holm, J. 1987. 'Elections in Botswana: Institutionalization of a New System of Legitimacy'. In F Hayward (ed). Elections in Independent Africa. London: Westview.

Holm, J and P P Molutsi (eds). 1989. Democracy in Botswana. Gaborone: Macmillan Botswana.

International IDEA. 1997.Voter Turnout from 1945 to 1997: A Global Report on Political Participation 2nd ed. Stockholm: International IDEA.

Independent Electoral Commission. 2002. 'Voter Apathy Study Report'. Gaborone: Independent Electoral Commission.

Legum, C. 1999. Africa Since Independence. Bloomington and Indianapolis: Indiana University Press. 
Mackenzie, W J M. 1967. Free Elections. George Allen and Unwin Ltd. \& K Robinson (eds). 1960. Five Elections in Africa: A Group of Electoral Studies. Oxford: Clarendon Press.

Massey, J A. 1967. Youth and Politics in Japan. Lexington, Mass: Lexington Books. Mgadla, P \& A Campbell. 1989. 'Dikgotla, Dikgosi and the Protectorate Administration'. In J Holm \& P P Molutsi (eds). Democracy in Botswana. Gaborone: Macmillan Botswana.

Modise, O. 2005. 'Voter Apathy Among the Youth'. Final year research project. Department of Sociology, University of Botswana.

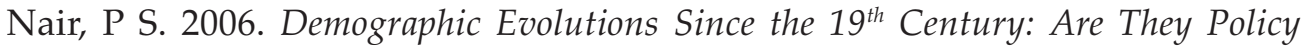
relevant? Inaugural Lecture Delivered at the University of Botswana, September.

Ngongco, L D. 1989. ‘Tswana political tradition: how democratic?' In J Holm \& P P Molutsi (eds). Democracy in Botswana. Gaborone: Macmillan Botswana.

Ntsabane, T. 1985. The Botswana Economy, Society and Polity in the Post-colonial Period. Gaborone: University of Botswana Election Study Project Research Report. 1993. 'Issues and Debates in Botswana's Electoral System'. In P P Molutsi \& B Otlhogile (eds). Consolidating Democracy: The Electoral Process under Scrutiny. Gaborone: Democracy Research Project Report.

Ntsabane, T \& C Ntau. 2000. 'Youth and Electoral Participation in Botswana'. PULA: Botswana Journal of African Studies 14(1).

Parson, J. 1984. Botswana: Liberal Democracy and the Labor Reserve in Southern Africa. Boulder: Lynne Rienner Publishers.

\& L Cliffe (eds). 1984. The 1984 Botswana General Elections: Class Politics and Competitive Elections. University of Botswana Election Study Project Research Report.

Picard, L. 1987. The Politics of Development in Botswana: A Model for Success? Boulder: Lynne Rienner Publishers.

Phorano, G. 1989. 'The School System: Should it be Teaching Democracy'. In J Holm \& P P Molutsi (eds). Democracy in Botswana. Gaborone: Macmillan Botswana

Prewitt, K. 1971. Education and Political Values. Nairobi: East Africa Publishing House.

Raditlhokwa, L. 1999. 'Reasons for Low Participation in Botswana's Politics'. The Youth Enquirer 1(2).

Ramatsui, P T. 1989. 'The School System: Is It Teaching Democracy?' In J Holm \& P P Molutsi (eds). Democracy in Botswana. Gaborone: Macmillan Botswana. Rogers, D. 1985. Adolescents and Youth. Englewood Cliffs: Prentice-Hall.

Schapera, I. 1947. Migrant Labor and Tribal Life: A Study of conditions in the Bechuanaland Protectorate. London: Oxford University Press. 
Somolekae, G. 1989. 'Citizen Participation in Democratic Politics'. In J Holm \& P P Molutsi (eds). Democracy in Botswana. Gaborone: Macmillan Botswana.

UN. 1995. Report of the International Conference on Population and Development. New York: United Nations Publication. 